\title{
Systems Thinking About SARS-CoV-2
}

\author{
Rainer Johannes Klement* \\ Department of Radiation Oncology, Leopoldina Hospital, Schweinfurt, Germany
}

Keywords: COVID-19, interdisciplinarity, public health, systemism, transdisciplinarity

\section{INTRODUCTION: SYSTEMISM AND SYSTEMS THINKING}

OPEN ACCESS

Edited by:

Thi H. Do,

Nguyen Tat Thanh University, Vietnam

Reviewed by:

Simon Grima,

University of Malta, Malta

Jacek Klich,

Kraków University of

Economics, Poland

Julie Abimanyi-Ochom,

Deakin University, Australia

*Correspondence:

Rainer Johannes Klement

rainer_klement@gmx.de orcid.org/0000-0003-1401-4270

Specialty section:

This article was submitted to

Health Economics,

a section of the journal

Frontiers in Public Health

Received: 11 August 2020

Accepted: 22 September 2020

Published: 28 October 2020

Citation:

Klement RJ (2020) Systems Thinking

About SARS-CoV-2.

Front. Public Health 8:585229.

doi: $10.3389 /$ fpubh.2020.585229
"[T]he good physician is a systemist: she prefers syndromes to isolated symptoms, places the body in its environment, and takes into account all the relevant levels of organization of matter, from the physical to the social." (1, pp.45-46).

This quote from Mario Bunge, the Argentinian physicist and philosopher who authored more than 500 papers and 50 books and died at age 100 this year, will be taken as the starting point for a critical appraisal of the role that systems thinking has played or not in the management of the SARS-CoV-2 epidemic.

The terms "systemist" in Bunge's quote and "systems thinking" are closely connected; the former relates to ontology, the latter to a corresponding epistemology. According to Bunge, a systemist is someone who is committed to the worldview of systemism which immune system, can be summarized in the formula "Every existent is either a system or part of a system" [(1), p.47]. A consequence of systemism is that the generation of knowledge about the world requires the usage of certain analytic skills in order to identify and understand systems, predict their behavior and modify them in order to produce desired effects (experimentation). This epistemological approach will be defined as systems thinking (2). Accordingly, a good physician should be a systems thinker, someone who tries to identify and take into account the various systems and their components that make up and interact with a given patient. The skills required for systems thinking consist of recognizing interconnections between parts of a system (the base level of systems thinking), identifying and understanding cause-effect feedback loops, understanding system structure, dynamic behavior and systems at different scales ("systems of systems"), and lessening a system's complexity through various methods such as reduction or abstraction (2). These analytic skills are not only important when dealing with an individual patient, but especially when the aim is to improve population health through cross-disciplinary research, i.e., multi, inter-, and transdisciplinarity $(3,4)$. Thereby, according to the definition of Rosenfield (3), multidisciplinarity means that researchers from several subdisciplines independently tackle a research problem in parallel or sequentially, i.e., without really working together, to contribute to an overall picture or solution. Interdisciplinarity also involves researchers working within their specific subdisciplines, but now jointly together. Finally, transdisciplinarity transcends disciplinary borders by working in a shared conceptual framework. Transdisciplinarity requires cross-disciplinary understanding between members of the research team and is necessary to obtain knowledge about emergent phenomena within systems [(4), p.86]. Such emergent phenomena cannot be explained by referring to lower levels of a system, i.e., via reduction. Transdisciplinary research and knowledge is therefore especially relevant for public health problems which involve emergent phenomena (5). 


\section{IMPLICATIONS OF SYSTEMS THINKING DURING THE SARS-COV-2 OUTBREAK}

Unfortunately, we live in an age in which fewer and fewer scholars have serious competence beyond their own increasingly narrow field of research (6). This is particularly reflected within the medical sciences, in which material reductionism, the view that every level of phenomena can be explained by causal effects of material particles at a lower level, is the default ontology $(7,8)$, apparently superseding crossdisciplinary, and in particular transdisciplinary research. While material reductionism has led to great advances in the natural sciences dealing with the non-living world, it faces serious problems when applied to sciences dealing with living, multicellular organisms and their societies both of which can be conceptualized as open systems with emergent properties $(9,10)$. Thus, physicians and public health authorities should resist reductionist thinking and instead try to identify and study system structures and causal loops of the problem at hand, integrating all relevant disciplines within an inter- and transdisciplinary approach.

Sahin et al. (11) recently developed a preliminary causal loop diagram (CLD) depicting many of the causal feedback loops within the environmental-health-socio-economic system of the SARS-CoV-2 problem. While their CLD is a valuable starting point for informing policy interventions against the SARS-CoV-2 and future outbreaks of other infectious pathogens, it has neglected the system of the individual person that the various medical disciplines are concerned with. I have therefore created a modified CLD based on the work of Sahin et al. (11) which includes the system of an individual and other components that I found to be under-represented in discussions about the SARS-CoV-2 crisis (Figure 1). These are briefly described in the following.

\section{A Functioning Immune System}

A functioning immune system on the level of the individual is a major determinant of the susceptibility to infection as well as the severity of symptoms. The fact that $\sim 40-45 \%$ of SARS-CoV-2 infections remain asymptomatic (12) indicates that innate and adaptive immunity have the power to effectively handle this virus. For example, triggering of innate immune adaptions through influenza vaccination has been proposed as a protective measure against COVID-19 severity (13), which indeed received some confirmation in (not yet peer-reviewed) observational studies $(14,15)$. It has also been proposed that the adaptive immune system may account for a significant protection in certain individuals through cross-reactivity between B- and T-cell epitopes of SARS-CoV-2 and other human coronaviruses (16). Indeed, cross-reactive T-cell responses against SARS-CoV2 associated with "common cold" coronaviruses have been detected in about $30-80 \%$ of unexposed individuals (17-20). Unfortunately, the computer models that had been used to justify the lockdown interventions in many Western countries had not taken these immune responses offering partial protection of a significant percentage of the population into account $(21,22)^{1}$-an example of "looking at only one or a few dimensions of the problem at hand" (reductionism) and "lack of expertise in crucial disciplines" (inter- and transdisciplinarity) that Ioannidis et al. identified as factors contributing to these models wrongly predicting COVID-19 fatalities by orders of magnitude (24).

Furthermore, the public is rarely informed that an optimally functioning immune system requires the presence or absence of certain factors. Some of these factors are studied within the transdisciplinary field of nutritional immunology. Healthy nutrition, i.e., an optimal macro-, micro- and trace nutrient composition, positively supports innate and adaptive immunity (path A in Figure 1). While the interactions between nutrition and the immune system are complex and pose a multidimensional problem (25), it is well-established that an adequate intake of protein and certain vitamins and trace elements is needed for an optimally functioning immune system and the containment of respiratory virus-induced inflammation $(26,27)$. For example, SARS-CoV-2, influenza and other respiratory viruses activate the cytoplasmic nucleotide-binding domain (NOD)-like receptor protein 3 (NLRP3) inflammasome in immune cells (typically monocytes and macrophages), which produces and activates interleukin (IL)- $1 \beta$ and further downstream cytokines, causing flu-like symptoms and tissue damage (28). Several nutrients and secondary plant substances have been shown to reduce NLRP3 inflammasome activation (29), among them vitamin C (ascorbic acid), which may be especially active against coronaviruses (30), or the ketone body $\beta$-hydroxybutyrate (31). Evidence for protective effects against COVID-19 has emerged for some of these nutrients, in particular zinc, selenium, $\mathrm{N}$-acetyl-cystein and vitamin $\mathrm{C}$, although it is limited to non-randomized studies $(27,32)$. The strongest evidence to date is available for vitamin D whose main natural supply is not through diet, but solar UV-B radiation on the skin (path B in Figure 1). Higher vitamin D levels have been linked to lower COVID-19 incidence, death rates and hospitalizations in epidemiological studies (33-35). First clinical data suggested that higher vitamin D levels are associated with less severe courses of COVID-19 $(36,37)$. A recent randomized controlled trial has shown a highly significant benefit of high vitamin D supplementation in COVID-19 patients: out of 50 patients receiving 25-hydroxyvitamin $\mathrm{D}$ in addition to standard treatment ${ }^{2}$ only one required intensive care unit admission compared to 13 out of 26 patients having not received vitamin D $(p<0.001)$ (38). Given the cost-effectiveness and safety of vitamin D and other immunesupporting nutrient supplements, some authors have rightfully argued that public health officials should encourage their

\footnotetext{
${ }^{1}$ I have thoroughly analyzed this and other problems in the modeling study of Flaxman et al. (22) in a German online article (23); for example, their model assumes that every infection causes a secondary infection until $100 \%$ of the population had been infected which is at odds with the observations of pre-existing immunity.

${ }^{2}$ The dose was $0.532 \mathrm{mg}$ (21280 I.U.) on day 1, followed by $0.266 \mathrm{mg}$ (10640 I.U.) on days 3 and 7 and $0.266 \mathrm{mg}$ weekly thereafter (38).
} 


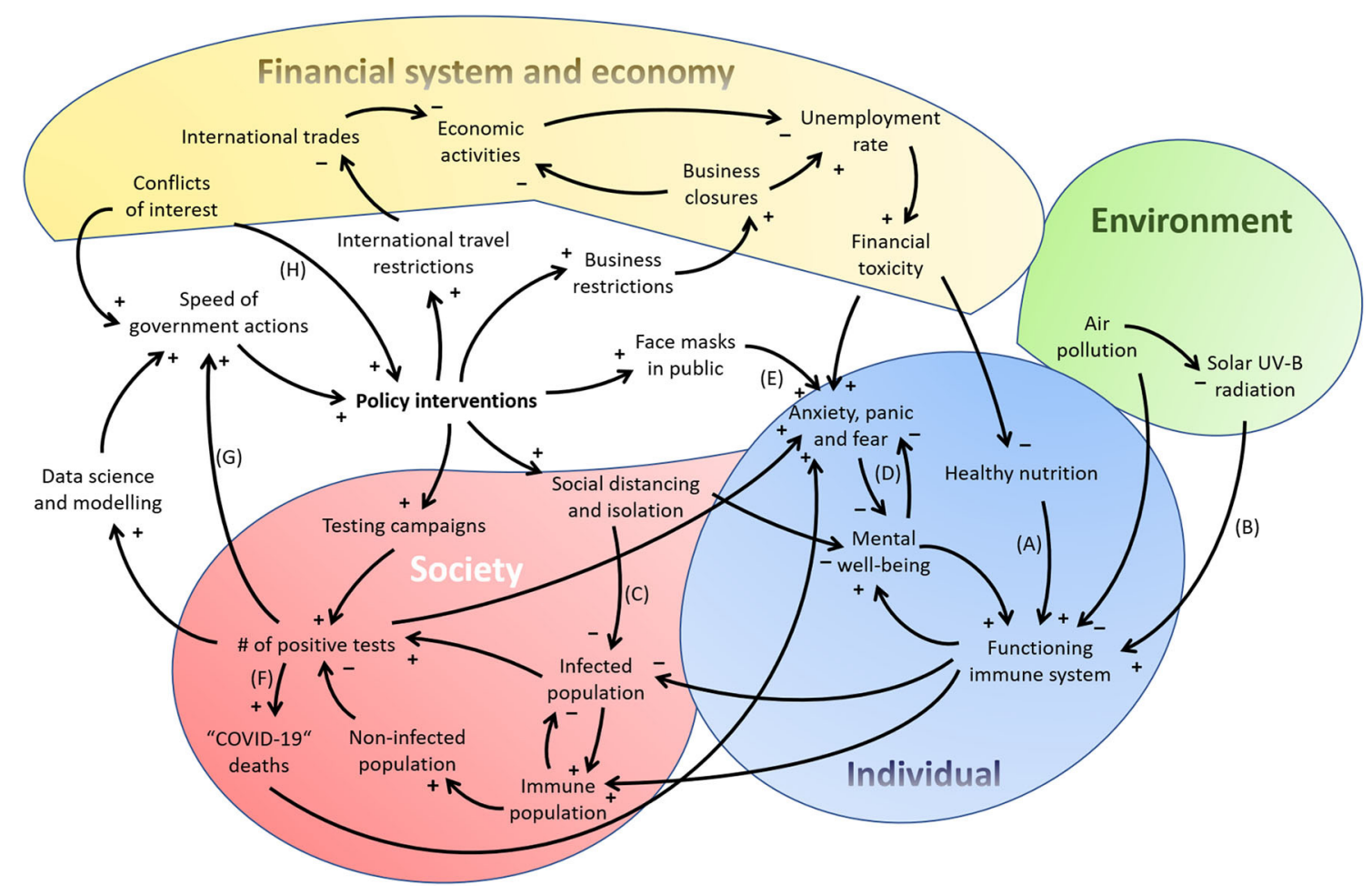

FIGURE 1 | A preliminary causal loop diagram displaying the complexity of the SARS-CoV-2 crisis' environmental-individual-socio-economic-political system. Based on Figure 1 of Sahin et al. (11), but extended in some components and simplified in others not relevant for my main arguments here.

adequate intake through a healthy diet and supplementation $(26,27)$.

Other important insights into immune system regulation come from the field of psychoneuroimmunology. This field investigates how psychological stress disrupts hormone and immune regulation; stress in mice, e.g., increases IL- $1 \beta$ through NLRP3 activation in the hippocampus (39). Mario Bunge goes even further by claiming that stress crosses not only three, but five disciplinary boundaries. He includes in this consideration "all levels of organization," up to the social, making stress a "psycho-neuro-endocrino-immuno-social disease" [(1), p.68]. Social distancing and isolation, while possibly decreasing the transmission of infectious pathogens (path $\mathrm{C}$ in Figure 1), also decreases mental well-being by increasing psychological stress, anxiety and fear (40-42) (loop D in Figure 1). Enforced prolonged wearing of face masks is also problematic, as demonstrated by Daniela Prousa who revealed that $\sim 60 \%$ of the German population experienced severe psychosocial problems already 5-7 weeks after installment of a public mask wearing decree (43) (path E in Figure 1).

\section{SARS-CoV-2 Tests and Statistical Illiteracy}

Testing for SARS-CoV-2 using polymerase chain reaction (PCR) or serum antibody tests is required to accurately map the spread of the disease within and across nations, although politics have failed to use such data in international cooperation (44). Furthermore, efforts to obtain reliable estimates for test sensitivity, specificity and the so-called base rate (or disease prevalence) have been sparse, although these quantities are essential for the logical inferences that can be made from a positive test result (45).

Some studies reported problems with both sensitivity and specificity of commercially available SARS-CoV-2 PCR tests (46, 47). Instead of acknowledging these limitations, positively tested individuals are still routinely nominated as infected individuals in the media, which is de facto wrong. Furthermore, many newspapers still simply report the daily or cumulative amount of positive PCR tests, without standardizing to the total number of tests performed and/or population number. This could lead to the impression that the prevalence of SARS-CoV-2 infection rises even if it declines or stays constant. For example, in Germany the number of weekly SARS-CoV-2 PCR tests has been increased to over one million until the end of August 2020, so that the absolute number of positive tests increased along with the number of performed tests, while the percentage of positive tests had remained $<1.5 \%$ since mid-May and $\leq 1.0 \%$ since end of June (48). Still, German chancellor Angela Merkel proclaimed in a press conference on August 28th that "the infection numbers have clearly risen during the past weeks" (49). Furthermore, in their discussion of the test statistics, even the Robert-Koch-Institute did not mention that the base rate 
needs to be accounted for when interpreting a positive test result (48), thereby committing what is called the base rate fallacy (50).

The "collective statistical illiteracy" of health care professionals, journalists and politicians $(51,52)$ is nothing more than a lack of transdisciplinary knowledge in mathematics and statistics. It is contributing to incorrect information about the spread of the SARS-CoV-2 with the effect of increasing both the public fear and impulsive actions from governments (paths $\mathrm{F}$ and $\mathrm{G}$ in Figure 1).

\section{Learning From Past Epidemics}

Given the leading role of the World Health Organization (WHO) in estimating the severity of infectious disease outbreaks, we should consider how the WHO has influenced policy decisions in the past. Doing so, it appears that the WHO has overestimated the severity of several recent "pandemics": SARS in 2002/2003, avian flu in 2005/2006 and Swine flu in 2009. This was likely due to the WHO basing its recommendations on a reductionist assessment made by molecular virologists (53), a mistake that I think is repeated in the current SARS-CoV-2 epidemic.

In addition, financial ties with the pharmaceutical industry of scientific advisors to WHO and international and national public health institutions have likely influenced public health policies during past virus outbreaks, e.g., driving a massive vaccination campaign during the swine flu pandemic that earned the pharmaceutical industry 18 billion Euro (53). Today, the WHO is financed to a large degree by the private Bill and Melinda Gates foundation from which it received more than 228 million US\$ in 2018 (54). The Bill and Melinda Gates foundation also funds several institutes that have large influence on decision-makers during the COVID-19 epidemic ${ }^{3}$, as well as the GAVI vaccine alliance which in turn funds the WHO $(55,56)$. Learning from past epidemics means that critical journalists and scientists must watch carefully if financial conflicts of interest might again influence policy decisions during the SARS-CoV-2 crisis (path $\mathrm{H}$ in Figure 1), in particular if these decisions cannot be justified by inter- and transdisciplinary science.

\section{DISCUSSION}

The complexity of the SARS-CoV-2 crisis, and most of the cross-disciplinary considerations associated with it, should have profound consequences for public health measures and personal behavior (57). If the system of an individual is considered, it must be asked why policies have not been directed more toward a positive message of self-responsibility in the sense that people can actively strengthen their immune system. Instead, the daily media messages about the latest rise in infection numbers (which as stated above are only

\footnotetext{
${ }^{3}$ These include the Johns Hopkins University which maintains the global SARSCoV-2 statistics, the German Robert Koch-Institute and the Charité Hospital in Berlin which employs Prof. Drosten, one of the leading government advisors during the crisis (55).
}

positively tested persons) as well as the installment of drastic measures all over the World fuel the narrative of us all being potential victims of a killer virus that can only be held back through physical barriers, extreme hygiene and ultimately vaccination (58) - a reductionist approach purely focused on the virus without considering the context of the human host, its immune system, microbiome and economic, social and natural environment. This raises many severe problems. For example, in poorer countries inadequate nutrition, financial toxicity and extreme stress induced by governmental lockdown measures without adequate relief strategies can lead to many deaths that remain invisible compared to those presented on COVID-19 dashboards; they can be attributed to a reductionist epidemiological and/or virological view of the problem (59). Along these lines, reductionist thinking raises many ethical issues, namely if avoiding risk of infection at any cost should outweigh other human values such as mental health, social contacts, dying in presence of the family, and basic human rights such as adequate nutrition and freedom of peaceful assembly. Here, more interdisciplinary discussions among health care professionals and scholars of the arts and humanities appear necessary.

As a final example, if systems thinking is employed it should be clear that the high death rates in Northern Italy in Spring 2020 could not simply be extrapolated to other countries given the characteristics of the population [very old, many smokers, high mesothelioma rates (60)], the environment (one of the most crowded and heaviest air-polluted regions in Italy) and the healthcare system ["decades of financial cuts, privatization, and deprivation of human and technical resources" (61)]. Although Italy has often been used for sustaining the mainstream "deadly virus" narrative for the public, such details about the healthcare system and population characteristics are specialist facts that make life more complicated, but need to be considered in order to avoid unnecessary public fear (58).

In summary, it is my argument that journalism, politics, and medicine involved within the SARS-CoV-2 crisis have maintained a rather simple narrative and reductionist thinking thus far. In my opinion we need more journalists interested in accurately informing the public about the complex facts associated with SARS-CoV-2; we further need more politicians willing to be advised from a much broader spectrum of industry- and financially independent scholars than just a few selected virologists and epidemiologists with putative financial or other conflicts of interest. Finally, we need more interand transdisciplinary science (62), in particular as retrospective analyses indicate that some drastic policy decisions had no clear benefit $(63,64)$, and may even have caused more harm than good $(43,59,65)$. My hope is that the critical systems perspective on the COVID-19 crisis presented here may be considered for the improvement of both public health and individual well-being.

\section{AUTHOR CONTRIBUTIONS}

RJK conducted the research and wrote and approved the manuscript. 


\section{REFERENCES}

1. Bunge M. Medical philosophy: conceptual issues. In: Medicine. 1st ed. Singapore: World Scientific Publishing Co Pte Ltd (2013). doi: 10.1142/8825

2. Arnold RD, Wade JP. A definition of systems thinking: a systems approach. Procedia Comput Sci. (2015) 44:669-78. doi: 10.1016/j.procs.2015.03.050

3. Rosenfield PL. The potential of transdisciplinary research for sustaining and extending lnkages between the health and social sciences. Soc Sci Med. (1992) 35:1343-57. doi: 10.1016/0277-9536(92)90038-R

4. Bhaskar R. Enlightened Common Sense: The Philosophy of Critical Realism. 1st ed. Hartwig M. editor. New York, NY: Routledge (2016). doi: 10.4324/9781315542942

5. Leischow SJ, Best A, Trochim WM, Clark PI, Gallagher RS, Marcus SE, et al. Systems thinking to improve the public's health. Am J Prev Med. (2008) 35:196-203. doi: 10.1016/j.amepre.2008.05.014

6. Matthews MR. Mario Bunge, systematic philosophy and science education: an introduction. Sci Educ. (2012) 21:1393-1403. doi: 10.1007/s11191-012-9530-0

7. Thompson RP, Upshur REG. Materialism and reductionism in science and medicine. In: Philosophy of Medicine: An Introduction New York, NY: Routledge. (1995). pp. 43-49. doi: 10.4324/9781315159843-5

8. Walach $\mathrm{H}$. Inner experience - direct access to reality: a complementarist ontology and dual aspect monism support a broader epistemology. Front Psychol. (2020) 11:640. doi: 10.3389/fpsyg.2020.00640

9. von Bertalanffy L. An outline of general system theory. Br J Philos Sci. (1950) 1:134-165. doi: 10.1093/bjps/I.2.134

10. Klement RJ, Bandyopadhyay PS. Emergence and evidence: a close look at Bunge's philosophy of medicine. Philosophies. (2019) 4:50. doi: 10.3390/philosophies4030050

11. Sahin O, Salim H, Suprun E, Richards R, MacAskill S, Heilgeist S, et al. Developing a preliminary causal loop diagram for understanding the wicked complexity of the COVID-19 pandemic. Systems. (2020) 8:20. doi: $10.3390 /$ systems 8020020

12. Oran DP, Topol EJ. Prevalence of asymptomatic SARS-CoV-2 infection. Ann Intern Med. (2020) 173:362-367. doi: 10.7326/M20-3012

13. Salem ML, El-Hennawy D. The possible beneficial adjuvant effect of influenza vaccine to minimize the severity of COVID-19. Med Hypotheses. (2020) 140:109752. doi: 10.1016/j.mehy.2020.109752

14. Zanettini C, Omar M, Dinalankara W, Imada EL, Colantuoni E, Parmigiani $\mathrm{G}$, et al. Influenza vaccination and COVID19 mortality in the USA. medRxiv. (2020) 2020.06.24.20129817. doi: 10.1101/2020.06.24.20129817

15. Fink G, Orlova-Fink N, Schindler T, Grisi S, Ferrer AP, Daubenberger $\mathrm{C}$, et al. Inactivated trivalent influenza vaccine is associated with lower mortality among Covid-19 patients in Brazil medRxiv [Preprint]. (2020) 2020.06.29.20142505. doi: 10.1101/2020.06.29.20142505

16. Yaqinuddin A. Cross-immunity between respiratory coronaviruses may limit COVID-19 fatalities. Med Hypotheses. (2020) 144:110049. doi: 10.1016/j.mehy.2020.110049

17. Grifoni A, Weiskopf D, Ramirez SI, Mateus J, Dan JM, Moderbacher CR, et al. Targets of T Cell responses to SARS-CoV-2 coronavirus in humans with COVID-19 disease and unexposed individuals. Cell. (2020) 181:1489501. doi: 10.1016/j.cell.2020.05.015

18. Nelde A, Bilich T, Heitmann JS, Maringer Y, Salih HR, Roerden M, et al. SARSCoV-2-derived peptides define heterologous and COVID-19-induced T cell recognition. Nat Immunol. (2020). doi: 10.1038/s41590-020-00808-x

19. Le Bert N, Tan AT, Kunasegaran K, Tham CYL, Hafezi M, Chia A, et al. SARS-CoV-2-specific $\mathrm{T}$ cell immunity in cases of COVID-19 and SARS, and uninfected controls. Nature. (2020) 584:457-62. doi: 10.1038/s41586-020-2550-z

20. Sekine T, Perez-Potti A, Rivera-Ballesteros O, Strålin K, Gorin J-B, Olsson A, et al. Robust $\mathrm{T}$ cell immunity in convalescent individuals with asymptomatic or mild COVID-19. Cell. (2020) 183:158-68. doi: 10.1016/j.cell.2020.08.017

21. Ferguson NM, Laydon D, Nedjati-Gilani G, Imai N, Ainslie K, Baguelin M, et al. Report 9: Impact of Non-Pharmaceutical Interventions (NPIs) to Reduce COVID-19 Mortality and Healthcare Demand. London. (2020)

22. Flaxman S, Mishra S, Gandy A, Unwin HJT, Mellan TA, Coupland H, et al. Estimating the effects of non-pharmaceutical interventions on COVID-19 in Europe. Nature. (2020) 584:257-61. doi: 10.1038/s41586-020-2405-7
23. Klement RJ. Die Fehlprognosen. Rubikon. (2020) Available online at: https:// www.rubikon.news/artikel/die-fehlprognosen

24. Ioannidis JPA, Cripps S, Tanner MA. Forecasting for COVID-19 has failed. Int J Forecast. (2020). doi: 10.1016/j.ijforecast.2020.08.004

25. Ponton F, Wilson K, Cotter SC, Raubenheimer D, Simpson SJ. Nutritional immunology: a multi-dimensional approach. PLoS Pathog. (2011) 7:e1002223. doi: 10.1371/journal.ppat.1002223

26. Calder PC, Carr AC, Gombart AF, Eggersdorfer M. Optimal nutritional status for a well-functioning immune system is an important factor to protect against viral infections. Nutrients. (2020) 12:1181. doi: 10.3390/nu1204 1181

27. Alexander J, Tinkov A, Strand TA, Alehagen U, Skalny A, Aaseth J. Early nutritional interventions with zinc, selenium and vitamin D for raising anti-viral resistance against progressive COVID-19. Nutrients. (2020) 12:2358. doi: $10.3390 /$ nu 12082358

28. Shah A. Novel coronavirus-induced NLRP3 inflammasome activation: a potential drug target in the treatment of COVID-19. Front Immunol. (2020) 11:1021. doi: 10.3389/fimmu.2020.01021

29. Alschuler L, Weil A, Horwitz R, Stamets P, Chiasson AM, Crocker R, et al. Integrative considerations during the COVID-19 pandemic. Explore. (2020) doi: 10.1016/j.explore.2020.03.007

30. Atherton JG, Kratzing CC, Fisher A. The effect of ascorbic acid on infection of chick-embryo ciliated tracheal organ cultures by coronavirus. Arch Virol. (1978) 56:195-99. doi: 10.1007/BF01317848

31. Youm YH, Nguyen KY, Grant RW, Goldberg EL, Bodogai M, Kim D, et al. The ketone metabolite $\beta$-hydroxybutyrate blocks NLRP3 inflammasome-mediated inflammatory disease. Nat Med. (2015) 21:263-9. doi: 10.1038/nm.3804

32. Alamdari DH, Moghaddam AB, Amini S, Keramati MR, Zarmehri $\mathrm{AM}$, Alamdari $\mathrm{AH}$, et al. Application of methylene blue -vitamin C -N-acetyl cysteine for treatment of critically ill COVID-19 patients, report of a phase-I clinical trial. Eur J Pharmacol. (2020) 885:173494. doi: 10.1016/j.ejphar.2020.173494

33. Panarese A, Shahini E. Letter: Covid-19, and vitamin D. Aliment Pharmacol Ther. (2020) 51:993-5. doi: 10.1111/apt.15752

34. Ilie PC, Stefanescu S, Smith L. The role of vitamin D in the prevention of coronavirus disease 2019 infection and mortality. Aging Clin Exp Res. (2020) 32:1195-8. doi: 10.1007/s40520-020-01570-8

35. Marik PE, Kory P, Varon J. Does vitamin D status impact mortality from SARS-CoV-2 infection? Med Drug Discov. (2020) 6:100041. doi: 10.1016/j.medidd.2020.100041

36. Radujkovic A, Hippchen T, Tiwari-Heckler S, Dreher S, Boxberger M, Merle U. Vitamin D deficiency and outcome of COVID-19 patients. Nutrients. (2020) 12:E2757. doi: 10.3390/nu12092757

37. Benskin LL. A basic review of the preliminary evidence that COVID-19 risk and severity is increased in vitamin D deficiency. Front Public Health. (2020) 8:513. doi: 10.3389/fpubh.2020.00513

38. Castillo ME, Entrenas Costa LM, Vaquero Barrios JM, Alcalá Díaz JF, Miranda JL, Bouillon R, et al. Effect of calcifediol treatment and best available therapy versus best available therapy on intensive care unit admission and mortality among patients hospitalized for COVID-19: a pilot randomized clinical study. J Steroid Biochem Mol Biol. (2020) 203:105751. doi: 10.1016/j.jsbmb.2020.105751

39. Iwata M, Ota KT, Li X, Sakaue F, Li N, Dutheil S, et al. Psychological stress activates the inflammasome via release of adenosine triphosphate and stimulation of the purinergic type 2x7 receptor. Biol Psychiatry. (2016) 80:1222. doi: 10.1016/j.biopsych.2015.11.026

40. Guo Q, Zheng Y, Shi J, Wang J, Li G, Li C, et al. Immediate psychological distress in quarantined patients with COVID-19 and its association with peripheral inflammation: a mixed-method study. Brain Behav Immun. (2020) 88:17-27. doi: 10.1016/j.bbi.2020.05.038

41. Banks J, Xu X. The mental health effects of the first two months of lockdown and social distancing during the Covid-19 pandemic in the UK. IFS Working Paper W20/16. London. (2020)

42. Majumdar P, Biswas A, Sahu S. COVID-19 pandemic and lockdown: cause of sleep disruption, depression, somatic pain, and increased screen exposure of office workers and students of India. Chronobiol Int. (2020) 37:1191200. doi: 10.1080/07420528.2020.1786107 
43. Prousa D. Studie zu psychologischen und psychovegetativen Beschwerden durch die aktuellen Mund-Nasenschutz-Verordnungen in Deutschland. PsychArchives [Preprint]. (2020). doi: 10.23668/psycharchives.3135

44. Everts J. The dashboard pandemic. Dialogues Hum Geogr. (2020) 10:2604. doi: $10.1177 / 2043820620935355$

45. Klement RJ, Bandyopadhayay PS. The epistemology of a positive SARSCoV-2 test. Acta Biotheor. (2020) 4:1-17. doi: 10.1007/s10441-02009393-w

46. Wernike K, Keller M, Conraths FJ, Mettenleiter TC, Groschup MH, Beer M. Pitfalls in SARS-CoV-2 PCR diagnostics. Transbound Emerg Dis. (2020). doi: 10.1111/tbed.13684

47. Lee SH. Testing for SARS-CoV-2 in cellular components by routine nested RT-PCR followed by DNA sequencing. Int J Geriatr Rehabil. (2020) 2:69-96

48. Seifried J, Böttcher S, Albrecht S, Stern D, Willrich N, Zacher B, et al. Erfassung der SARS-CoV-2-Testzahlen in Deutschland (Stand 2.9.2020). Epidemiol Bull. (2020) 36:15-8. doi: 10.25646/7123

49. Bundesregierung Deutschland. "Nehmen Sie das Virus weiterhin ernst!" (Pressekonferenz von Bundeskanzlerin Merkel am 28. August 2020). (2020) Available online at: https://www.bundesregierung.de/breg-de/themen/ buerokratieabbau/kanzlerin-sommer-pk-1780768 (accessed September 6, 2020)

50. Bar-Hillel M. The base-rate fallacy in probability judgments. Acta Psychol. (1980) 44:211-33. doi: 10.1016/0001-6918(80)90046-3

51. Gigerenzer G, Gaissmaier W, Kurz-Milcke E, Schwartz LM, Woloshin S. Helping doctors and patients make sense of health statistics. Psychol Sci Public Interes Suppl. (2007) 8:53-96. doi: 10.1111/j.1539-6053.2008.0 0033.x

52. Gigerenzer G, Gray JAM. Better Doctors, Better Patients, Better Decisions. Envisioning Health Care 2020. 1st ed. Cambridge, MA, London: The MIT Press. (2011). doi: 10.7551/mitpress/9780262016032.001.0001

53. Keil U, Schönhöfer P, Spelsberg A. The invention of the swine-flu pandemic. Eur J Epidemiol. (2011) 26:187-90. doi: 10.1007/s10654-011-9573-6

54. World Health Organization. Voluntary Contributions by Fund and by Contributor, 2018. (2019) Available online at: https://www.who.int/about/ finances-accountability/reports/A72_INF5-en.pdf (accessed May 14, 2020)

55. Wagner E. The Gates Foundation's Vaccination Activism. Multipolar. (2020) Available online at: https://multipolar-magazin.de/artikel/the-gatesfoundations-vaccination-activism (accessed May 14, 2020)
56. GAVI Alliance. The Bill \& Melinda Gates Foundation. (2020). Available online at: https://www.gavi.org/investing-gavi/funding/donor-profiles/billmelinda-gates-foundation (accessed October 10, 2020).

57. Klement RJ. The SARS-CoV-2 crisis: a crisis of reductionism? Public Health. (2020) 185:70-1. doi: 10.1016/j.puhe.2020.06.019

58. Walach H. Brainmasks - how the Covid19-Crisis generates new narratives. SSRN Electron J [Preprint]. (2020). doi: 10.2139/ssrn.3608584

59. Ray D, Subramanian S. India's lockdown: an interim report. Ind Econ Rev. (2020). doi: 10.1007/s41775-020-00094-2

60. Mensi C, De Matteis S, Catelan D, Dallari B, Riboldi L, Pesatori AC, et al. Geographical patterns of mesothelioma incidence and asbestos exposure in Lombardy, Italy. Med Lav. (2016) 107:340-55.

61. Armocida B, Formenti B, Ussai S, Palestra F, Missoni E. The Italian health system and the COVID-19 challenge. Lancet Public Heal. (2020) 5:e253. doi: 10.1016/S2468-2667(20)30074-8

62. Klement RJ. The SARS-CoV-2 crisis: has medicine finally entered a reductionist era? Complement Med Res. (2020) 27:207-8. doi: 10.1159/000510453

63. Wieland T. A phenomenological approach to assessing the effectiveness of COVID-19 related nonpharmaceutical interventions in Germany. Saf Sci. (2020) 131:104924. doi: 10.1016/j.ssci.2020.104924

64. Atkeson AG, Kopecky K, Zha T. Four Stylized Facts About COVID-19. Cambridge, MA. (2020) Available online at: http://www.nber.org/papers/ w27719

65. Miles D, Stedman M, Heald A. Living with COVID-19: balancing costs against benefits in the face of the virus. Natl Inst Econ Rev. (2020) 253:R60R76. doi: 10.1017/nie.2020.30

Conflict of Interest: The author declares that the research was conducted in the absence of any commercial or financial relationships that could be construed as a potential conflict of interest.

Copyright (c) 2020 Klement. This is an open-access article distributed under the terms of the Creative Commons Attribution License (CC BY). The use, distribution or reproduction in other forums is permitted, provided the original author(s) and the copyright owner(s) are credited and that the original publication in this journal is cited, in accordance with accepted academic practice. No use, distribution or reproduction is permitted which does not comply with these terms. 